\title{
ОТ ЭСКИЗОВ ДО ТВОРЧЕСТВА - АНАЛИЗ СОВРЕМЕННЫХ ЖИВОПИСИ НА ТЕМУ БАССЕЙНА РЕКИ ХУАНХЭ
}

Хуан Юаньпэн

Аннотация. Художник должен быть не только удовлетворен данными изображения, полученными с помощью электронного оборудования, но и должен часто входить в жизнь людей, возвращаться к телу картины и встречаться лицом к лицу, чтобы испытать опыт рисования на природе. Это обязанность художника. Восприятие эскизов как источника творчества, а затем поиск в жизни, совершенствование элементов творчества, создание произведений, наполненных истинными чувствами, и постепенное формирование собственного языка в процессе непрерывного творчества и исследования - единственный путь для прекрасного художника.

Ключевые слова: Создание эскизов Моделирование Цвета Реальная жизнь Культурная традиция

В эту эпоху быстрого технологического развития получение изображений стало очень удобным: художники должны быть не только удовлетворены данными изображений, полученными с помощью электронного оборудования, но и должны часто погружаться в жизнь людей, возвращаться к телу живописи и лицом к лицу с природой. Опыт рисования эскизов в середине - это то, к чему должен придерживаться художник. Восприятие эскизов как источника творчества, а затем поиск в жизни, совершенствование элементов творчества, создание произведений, наполненных истинными чувствами, и постепенное формирование собственного языка в процессе непрерывного творчества и исследования - единственный путь для прекрасного художника. Сегодня, выполняя множество зарисовок, художники должны отстаивать истину, добро и красоту, любить жизнь, уделять внимание реальному опыту, истинным чувствам и усердно учиться для миссии, данной нам в новую эпоху. Это задача и миссия, стоящие перед каждым художником.

\section{-: миссия творчества художника в новую эпоху требует отражения реальной жизни.}

Буквально “Эскиз”: это дух искусства живописи. Художник должен постоянно идти вглубь жизни по пути художественной практики и постоянно впитывать свежее питание перед лицом жизни, чтобы способствовать росту и развитию искусства. (Цитата 1) Часто отправляйтесь на природу, чтобы набросать опыт и творчество, это эффективный способ приблизиться к природе и умерить искусство живописи, это эффективный способ для художника непосредственно прикоснуться к природе кистью. Неважно, древние или современные, все люди сходятся во мнении, что природа и человеческая жизнь являются источником искусства. Прекрасный художник в мире тысяч людей должен уметь «рисовать картины там, где он видит», потому что только накапливая искусство посредством эскизов, он может достичь свободного и гибкого состояния «только из головы» при создании. Использование художником кистей для выражения реальной жизни также стало свидетелем большого развития и изменений в Китае со времени 40-летия реформ и открытости, что также является особым значением эскизов. С помощью зарисовок в природе люди открыли световые и цветовые пространства, изучили законы живописи и суммировали полные знания и техники живописи. Эскиз - это эффективное получение жизненных элементов искусства у источника. Как художник, вы не должны уезжать на долгое время и не должны этого делать, иначе вы не избежите недостатков бледности, концепции и манипуляций. Как говорит Балтус:“Художники, которые находятся вне природы, к весне умрут от жажды.”

В исследовании Китайской академии масляной живописи учитель Ян Фэйюнь однажды сказал: “Зарисовка - это дар живописи, который делает нас набожными, невинными и более любящими жизнь.” (Цитата 2) Учитель Ян придает большое значение наброскам на местах в своем учении и часто приводит нас к рисованию в некоторых отдаленных горных деревнях, чтобы испытать жизненный опыт местных жителей. Поскольку бассейн реки Хуанхэ не только обладает уникальной геоморфологической средой, но и имеет давнюю историю гуманитарных наук и культуры, многие зарисовочные работы Китайской академии живописи маслом проводятся в некоторых представительных древних городах и деревнях в бассейне реки Хуанхэ. Такие работы, как «Старик оленеводческой фермы» и «Стойкость» (Ил.1), - это наброски г-на Ян Фэйюня в сельской местности на севере провинции Шэньси в последние годы. Эти работы были хорошо восприняты людьми в отрасли. Простое изображение крестьянина на картине прыгнуло передо мной, и искренность картины приветствовала меня.Тяжелое чувство картины сделало меня очень эмоциональным и оказало большое влияние на мою картину. В зарисовках Шицзягоу в Шэньси я также создавал такие работы, как «Новые туфли», «Голова старой деревни» и «Дядя Ши».

Искусство приходит из жизни. Творчество искусства должно быть близко к жизни. Жизнь не просто относится к собственной жизни, но многоуровнева и многогранна. Молодые художники должны погрузиться в обширную природу, чтобы испытать жизнь в глубине, постоянно поглощать свежую пищу в личной жизни, стимулировать сильное желание творить, а затем искренне выражать свои чувства жизни на картине. Работа 
«Новые туфли» (Ил.2) изображает старую мать Шицзяго, которая делает пару новых туфель для своего сына, который работает за границей. В этот день проходит фестиваль середины осени. Она съела мне несколько лунных тортов, которые она избила сама, и рассказала о мелочах о ее сыне. Потом я вспомнила свою маму. Я чувствовала боль в своем сердце, и мои глаза были влажными. Я пытался вписать это в мою работу. Альбом для рисования соединяет любовь между человеком и природой. Пусть мы найдем красоту и движение жизни в альбоме. (Цитата 3)

二: Начиная с эскизов, обратите внимание на утонченность и обобщение истинных чувств и моделирования цветов в творчестве.

Большинство наших занятий по рисованию началось, когда мы учились в школе, а сейчас в сфере домашнего обучения Академия изящных искусств часто начинает с работ мастера Лин, а затем рисует модель гипса вместо непосредственного рисования эскизов. Реалистичные зарисовки портретов и человеческих тел. Первые два этапа - рассказать вам о методе и языке характеристики при создании масляной живописи, чтобы учащиеся могли понять традиции и стандарты масляной живописи по гипсовым моделям и мастерским работам, а также научиться тонкости и обобщению моделирования и цвета. Затем с помощью набросков практики и обучения, чтобы улучшить мое понимание, оттачивать навыки масляной живописи и в дальнейшем медленно вкладывать эти результаты обучения в свое собственное творение. Если вы не знаете первые два основных процесса, перейдите непосредственно к эскизу, ваш эскиз всегда будет оставаться на объекте, и многие творческие изображения и цветовые приложения не могут быть ограничены эскизом. При черчении необходимо обратить внимание на традиционную систему норм, и черчение полезно. С одной стороны, нам нужно получить истинные ощущения жизни и вдохновения для творчества с помощью эскизов, с другой стороны, мы должны использовать наши эмпирические знания, чтобы научиться извлекать и обобщать материалы в жизни, а затем переходить от эскизов к творчеству. Это вопрос базовой подготовки, но также и вопрос практики. Если наше творение остается только на эскизах, картина легко станет графической, бледной и слабой, что затруднит ее превращение в хорошую работу.

Как распознать разницу между моделированием изображения и изображения изображения в нашем создании масляной живописи является важной теоретической темой. Изображение моделирования в масляной живописи не является реальным, но художник воссоздал масляной краской на плоскости холста на экране. Изображение моделирования персонажа в плоском трехмерном пространстве очень отличается от реального изображения , В процессе планаризации мы должны обратить внимание на объяснение его светлой и темной границы. Особенно при выражении персонажей в произведениях, граница между светом и тьмой должна быть пронизана с головы до пят. Даже если вы наденете одежду, вы должны научиться описывать границу между светом и тьмой. Из-за светлых и темных границ, вы можете сделать ваше изображение полным.

При создании мы должны передать смысл нарратива картины через образ персонажа. Обработка структуры человеческого тела не должна быть полностью истинной. Требуется, чтобы художник уточнил и суммировал, и далее обрабатывал обработку в соответствии с потребностями картины и чувствами художника. Например, человек из работы Чжун Хана «Идет горный дождь» (Ил.3) , руки и модель могут быть не такими толстыми, форма имеет форму。Слон должен идеализировать руку, и художественная обработка может выделить или укрепить или подчеркнуть отношения и увеличить его кости и сухожилия. Такие обработки полностью переосмыслены или построены художником через объект. В своей работе г-н Чжун сначала использовал эскиз для выполнения процесса моделирования, а затем уточнил цвета в масляной живописи.В последующей работе «Миюнь» это изображение было обработано и уточнено снова, создавая жесткое и высокое изображение, так что медленно Завершено создание, оставив нам драгоценное произведение искусства. Утонченность формы и цвета в ней - самая фундаментальная вещь в искусстве масляной живописи, но мы иногда игнорируем это или недостаточно обращаемся с этим. Из-за камеры мы не можем отличить изображения от пластики. Поэтому теоретические вопросы масляной живописи, которые мы собираемся обсудить сегодня, должны по-прежнему подчеркивать понимание самой формы и цвета.Историческая картина «Через Желтую реку на восток» (Ил.5), созданная г-ном Чжун Ханом, использует угол обзора, в котором он смотрит вверх, изображая героические амбиции лидеров Коммунистической партии Китая пересечь Желтую реку и продвинуться на Центральные равнины под ней. под руководством председателя Мао. Вздымающаяся река принесет новую надежду новому Китаю. Абстракция и краткое изложение форм и цветов на картинке достойны нашего многократного размышления и изучения.

Уточнение и обобщение цветов в масляной живописи одинаково важны. Использование исследований светлых цветов в масляных картинах зародилось в импрессионизме. Художники-импрессионисты долгое время изучали эффекты светлого цвета и воздуха с помощью эскизов и часто рисуют несколько изображений одного и того же объекта в разное время и свет, изменяя цвет естественного света. Выражая мгновенное чувство, они использовали много картин на одну и ту же тему, чтобы экспериментировать с идеальным выражением цвета и света. Когда мы лучше понимаем цвета через изучение работ импрессионистов и зарисовок, мы можем лучше 
использовать цвета, чтобы выразить свои чувства, а затем выразить их в наших творениях. Следует отметить, что цвет создания недостаточно набросать, его необходимо обобщить и уточнить, а также с помощью множества практических упражнений, чтобы сформировать свой собственный цветовой опыт, цветовую систему и погоню. Поскольку цвет представляет собой целую серию цветов, изменения в условиях освещения и географической среде различны, невозможно отобразить все цвета на экране, иначе ваша картина не сможет сформировать гармоничный тон. По крайней мере, это не отражает стремление художника к цвету и тону. Поэтому иногда вам следует взять на себя инициативу удалить некоторые цвета, как вы можете нарисовать хорошую картинку в случае меньшего количества цветов или только 4 или 5 цветов. Это в пределах цвета, что немногие цвета используются, чтобы обдумать, так что картина представляет богатый и гармоничный цвет, который является диалектическим и единым отношением.

В картинах маслом с бассейном Хуанхэ в качестве темы многие коллеги-художники уже имеют свои собственные занятия и выглядят в цветном выражении. Мой сосед Хуан Шэнсянь - отличный молодой художник, он также написал много работ на тему бассейна Хуанхэ. «Юань Шангренцзя-Нуаньянг» (Ил.5) - одно из моих любимых произведений. Автор суммирует цвета на картинке. Небо близко к однородному теплому серому, земля почти все того же желтовато-коричневого цвета, маленький кусочек темного цвета на дальних холмах исчезает, и луч желтого солнечного света наклоняется на расстоянии, поэтично. Я считаю, что объект не совсем такой, у него должен быть свой набор методов и занятий. Кроме того, г-н Чжун Цзяньцю, преподаватель в России, также любит тему «Хуанхэ»: он настаивает на набросках в Хуанхэ более десяти лет. «Утро Хуанхэ» это создание ландшафта после зарисовок. Это также одна из моих любимых работ в Желтой реке. Выбор высоких гор и вод дает людям ощущение неба Хуанхэ. Вода Желтой реки сияла белым утренним светом, и изгиб исчез между горами и горизонтом. Отрегулируйте цвет между ограниченным серым и желтым фиолетовым, чтобы добиться цветовой координации и насыщенности изображения, и картина будет очень хорошей. Чувство пространства и перспективы - это то, на что мы не обращаем внимания больше всего, очень редко можно выразить чувство отдаленной перспективы очень легко и ярко. Это неотделимо от многолетнего накопленного опыта зарисовок и мастерства цвета, стремления к цвету и выражения эмоций.

При завершении картины, в дополнение к яркости и ощущениям от эскиза, необходимо дополнительно усовершенствовать богатое содержание картины с помощью рисунка и изображения, чтобы такая работа могла быть более долговечной и законченной. В своих недавних творениях я часто использую графические материалы. В этом году, когда я был силен осенью, я поехал в Гоцзягоу, сельскую местность в северной части провинции Шэньси, чтобы рисовать, и там также есть очень представительное место. «Дом» (Ил.6) - последнее творение после зарисовок. Солнечным и солнечным днем я поднялся на полпути к горе и вошел во двор этой семьи.К приближался вечер, все было так тихо и красиво, и я не мог удержаться, подняв коробку с картинками. На второй день в полдень, когда он снова посетил милого дядю Го, он возвращался с земли и собирал тяжелый груз картошки.Тетя Го зажгла печь и готовила обед, который был более ярким, чем вечер. Дыхание жизни. Цыплята свободного выгула едят счастливо, кукуруза на подоконнике накапливается еще больше и висит на стене, она выглядит очень ярко, а красный фонарь еще ярче под ярким солнцем, сцена осеннего урожая, ощущение дома Я хочу записать эту прекрасную пьесу перед Yueran. После возвращения я воспользовался чувством зарисовок и создал эту работу с помощью множества материалов, снятых в то время по телефону. Поскольку многие вещи происходят мгновенно, дядя Го быстро шагает перед ним энергичным темпом, и цыплята со свободным диапазоном также имеют разную динамику: их необходимо получать с помощью данных изображения, чтобы получить более богатую информацию, а дальнейшая обработка и уточнение могут быть лучше Совершенствуй картинку. Оставьте те, которые полезны для картинок и тем, удалите ненужные, удалите сложные и упростите их, подчеркните изысканные вещи. Конечно, начиная с более высоких требований, как молодой художник, который только что вошел в дверь искусства, моя картина нуждается в более тщательном изучении, прежде чем искусство может быть выведено на более высокий уровень.

三 При черчении и создании мы должны обратить внимание на сочетание традиции масляной живописи и местной культурной традиции.

В процессе практики от эскизов до создания мы должны обратить внимание на традиции масляной живописи и усердно работать над онтологическим выражением языка масляной живописи. Судя по традиции масляной живописи, из-за изобретения камеры, под воздействием картинок и изображений и изменений в социальной среде, традиция масляной живописи, созданная в Европе, постепенно теряется. Европейские и американские художники проводили модернистские исследования в 20-м веке и проводили практические исследования планаризации, постепенно утрачивая традиции искусства масляной живописи, особенно традиции пластического искусства. Живопись маслом вошла в Китай за сто лет исследований. От старшего поколения гна Сюй Бэйхуна до г-на Цзинь Шанъяй, г-на Ян Фэйюня, включая современных молодых художников, мы унаследовали и создали снова. Это наследие далеко от европейской традиции пластического искусства. Даже если мы уезжаем за границу, чтобы остаться там на некоторое время, у нас есть определенные чувства, но после возвращения мы будем продолжать развиваться и вырождаться, что заставляет наше понимание традиции 
масляной живописи сегодня стремиться к мелкий. Поэтому, делая наброски и творения, мы часто должны возвращаться к классическим работам мастера, снова изучать глубокое копирование и продолжать изучать и исследовать европейскую традицию масляной живописи в духе поиска происхождения.

В педагогической коммуникации и творческой практике Китайской академии живописи маслом, она придает большое значение изучению европейской традиции масляной живописи. Дин Ян Фэйюнь также часто вывозит нас за границу, чтобы исследовать и общаться, копируя эскизы. Летом 2018 года г-н Ян также привел нас к работам всемирно известного мастера-подражателя из Музея Русского Эрмитажа, и для меня большая честь участвовать в планировании этого мероприятия. Благодаря обучению копированию и черчению в полевых исследованиях, давайте более интуитивно познакомимся с техникой масляной живописи и языковым выражением мастера. Это оказало большое влияние на мои художественные знания и даже будущие творения. После копирования выставки, чтобы вернуться в Китай, г-н Ян отвез нас в северную часть бассейна Желтой реки, чтобы сделать эскиз и создать множество превосходных работ. В нескольких новых крестьянских портретах Янга наиболее ярко отражены наследие и выражение традиции масляной живописи. Учитель Ян часто предупреждает нас, что создание масляной живописи все еще должно вернуться к исследованию и выражению языка онтологии масляной живописи.

В процессе изучения западной традиции масляной живописи мы иногда закладываем прочную основу, но направление будет отклоняться, что затруднит локализацию нашего языка масляной живописи. Поэтому в процессе практики масляной живописи мы должны изучить, как китайская родная культура отражается в масляной живописи, что не только обогащает средства художественного творчества, но и дает нам богатые способы изучения новых художественных форм и новых эстетических правил живописи. почва. В процессе локализации масляной живописи появилось много выдающихся работ на тему бассейна Желтой реки. «Старый пересекающий Желтую реку», созданный покойным старым профессором Центральной академии художеств и известным художником-маслом художником Ай Чжунсинь, - прекрасная работа, которая никогда не забудет нас. Картина использует реализм и разумное использование языковой традиции масляной живописи и показывает историческое положение команды Красной армии, возглавляемой Коммунистической партией Китая и смело продвигавшейся к линии фронта перед лицом национального кризиса сумасшедшего вторжения японского империализма. Художник рисует вид на бурную Желтую реку с точки зрения нисходящего потока, и команда Красной Армии собирается на пароме, чтобы сформировать готовый импульс.Красивые и великолепные горы и реки на экране пересекаются с героическим импульсом команды, создавая потрясающий визуальный эффект. В процессе локализации масляной живописи она установила модель для китайской масляной живописи для молодого поколения.

В дальнейшем исследовании и практике современной китайской масляной живописи необходимо учиться на элементах традиционной китайской культуры, и в то же время следует также учиться на опыте других художественных произведений и уделять внимание «синизации» художественной концепции живописи в произведениях. Художественные концепции нуждаются в культурной среде и окружающей среде. Ожидается, что мы откроем новую веху в развитии живописи на основе истории, чтобы добиться наследования, инноваций и трансформации системы масляной живописи. (Цитата 4) Хороший пример - масляная картина долгого ветра на Желтой реке, нарисованная известным художником Ван Кеджу в 2017 году. Это произведение масляной живописи, которое длилось четыре года, прошло более 5000 километров и имело длину 161,6 метра, открыло прецедент для создания длинного свитка масляной живописи в Китае, а также было воплощением мечты художника в его творчестве. Художник не только создал великие произведения матери-реки китайской нации своими стропилами, но также выразил величественный импульс реки Тангтанг с древних времен до наших дней, упорство размножения и размножения китайской нации и эпическую жизнь превратностей жизни, более глубоко захватывая и выражая Желтую реку. Бесконечный смысл как символ духовной культуры китайской нации. "Желтая река"(Ил.7) длинным свитком масляной живописи - произведение времен родных гор и рек. Он показывает не только реку истории и реку духа, но и шедевр искусства, созданный духом времени. Охват реки это изображение духа времени. Возвышающиеся горы и реки - это образ Родины и сила борьбы. Красивые пейзажи или крутые пейзажи полны глубокой любви людей к рекам страны. Протекающая река - это духовный флаг самосовершенствования и настойчивости нашего народа.

\section{四: часто задаваемые вопросы от эскизов до создания}

В процессе практики от эскизов до творчества, благодаря наставлениям джентльменов и обменам между коллегами по искусству, я также обнаружил много проблем, вкратце, коллег по искусству Чэнь Юйю, чтобы обсудить вместе.

Во-первых, многие творения кажутся поверхностными, и нет глубокого смысла для утончения жизни. Многие из явлений жизни превращаются в картины и превращаются в картины, или просто в пару набросков на месте, и оттенок позади не может идти в ногу. Многие картины сосредоточены только на предмете, а не на глубоком опыте людей и понимании предмета. В последние годы появилось много пейзажных картин на тему Хуанхэ. Некоторые художники выполнили работу кистью швабры на месте более чем за два часа. Хотя 
некоторые работы очень искусны, географические характеристики многих работ не ясны, и их нельзя рассматривать как хорошую работу. Есть также много картин сельских дядей, в работах они носят старую черную и синюю одежду и смеются вместе от радости, очень счастливы. За год тяжелой работы фермеры получают такой небольшой урожай: многие дети ездят на работу в город, а их нет рядом, часто заботясь о своих средствах к существованию. Иногда в деревне остаются только старики и дети. В их жизни много глубоких коннотаций, а не несколько людей, смеющихся над входом в деревню. Мы часто снимаем сцену в нашей жизни, фотографируем, а затем рисуем. Вместо того, чтобы найти чувства от жизни, а затем через организацию изображения, чтобы углубиться в жизнь, а затем создать. Чтобы создать типичный образ в типичной среде творчества, нужно не только сосредоточиться на процессе исполнения, но и глубоко задуматься.

Во-вторых, хорошие картины должны быть простыми и лаконичными. Многие художники сегодня очень способны рисовать, и с помощью фотографий легко нарисовать много деталей, но они не могут войти и выйти. После рисования это для подробного описания, но после того, как оно вышло, его необходимо уточнить и обобщить. Художнику приходится разбираться с картиной, подчеркивать утонченные вещи и разгонять ненужные вещи. Суть в том, что, пока вы что-то надеваете, вы должны говорить, и все вещи, которые не могут говорить, удаляются, и, наконец, образ установленного субъекта становится более ярким. Поэтому, когда вы рисуете картину, книги, которые вы читаете, и истории, которые вы читаете, должны быть объединены, и тогда вы можете создать искру вдохновения. Вдохновение не может быть предопределено при создании, оно иногда естественным образом синтезируется после того, как входит автор. Иногда творчество - это искра, созданная столкновением двух не связанных между собой вещей.

В-третьих, индивидуализация языка. Текущие процедуры рисования слишком очевидны, и я чувствую себя очень уставшим, увидев их. Некоторым ученикам нравится изучать объективный язык учителя. Все в классе рисуют так. Выражение объективного языка масляной живописи очень похоже, поэтому трудно создавать отличные работы. Поэтому наше искусство также должно иметь большее богатство. Кроме того, зарисовка должна отражать реальность, а не копировать реальность, не копировать реальность. В процессе зарисовок художники должны добавлять личные эмоции.

В-четвертых, мы должны обратить внимание на развитие культурных знаний в творчестве, и мы должны отражать стремление к красоте человеческой природы. В предисловии к выставке г-на Чжун Хана г-н Фань Диан, председатель Ассоциации художников Китая, писал, что «поколение художников-г-жей Чжун Хана уделяет особое внимание культурной коннотации, и его необычайная мудрость заключается в постоянном размышлении о культуре. Современная природа коннотации заключается в том, чтобы сочетать идеал глубокого выражения искусства с ответственностью за реалистическую заботу о культуре. (Цитата 5) «Наши молодые художники часто изучают художественные знания и техники рисования, но часто Не обращая слишком много внимания на проблему культурного культивирования, трудно создать культурный оттенок в произведениях. Наконец, в нем подчеркивается, что слова детей недобросовестны: как молодые художники, взгляды слегка предвзяты или завышены, и я надеюсь, что все учителя поймут.

\section{Вывод}

Любите жизнь, приближайтесь к природе и возвращайтесь к наброскам, обращайте внимание на утонченность и изящество формы и цвета, усиливайте эстетическое стремление в работе, давайте с ясным взглядом рассмотрим проблемы современного творчества и продолжим исследовать в духе поиска происхождения и спрашивания в естественном Возвысьте свое искусство и индивидуальность среди простых элементов и постарайтесь создать для миссии, возложенной на нас новой эрой. Я хочу, чтобы все коллеги по искусству могли кататься на ветру и волнах в океане искусства и создавать более прекрасные произведения искусства.

\section{СПИСОК ИЛЛЮСТРАЦИЙ}

1 詹建俊，“致辞”《中国油画写生作品汇展作品集》，广西美术出版社2008年出版

Чжан Цзяньцзюнь, «Речь», «Коллекция китайской живописной живописи, выставка эскизов», Издательство Guangxi Fine Arts, 2008

2 杨飞云, 《写生的恩赐》, 《美术大观》2011年第一期

Ян Фэйюнь, «Дар зарисовки», «Великий вид изобразительного искусства», выпуск 1, 2011

3 黄远鹏, 《艺术的本分》，《美术》2019年第六期

Хуан Юаньпэн, «Обязанность искусства», «Искусство», выпуск 6, 2019 г.

4 张晓杰, 《中国元素在当代艺术中的体现》, 《名作欣赏》2012年27期

Чжан Сяоцзе, «Представление китайских элементов в современном искусстве», «Оценка известных произведений», выпуск 27, 2012

5 范迪安, 《厚土人文-20世纪油画名家——钟涵》，文化艺术出版社2013年出版

Фань Диан, «Художник-живописец Хоу Ту ХХ века - Мастер живописи Чжун Хан», Издательство «Культура и искусство», 2013 



\section{Картины художников и фото о них :}

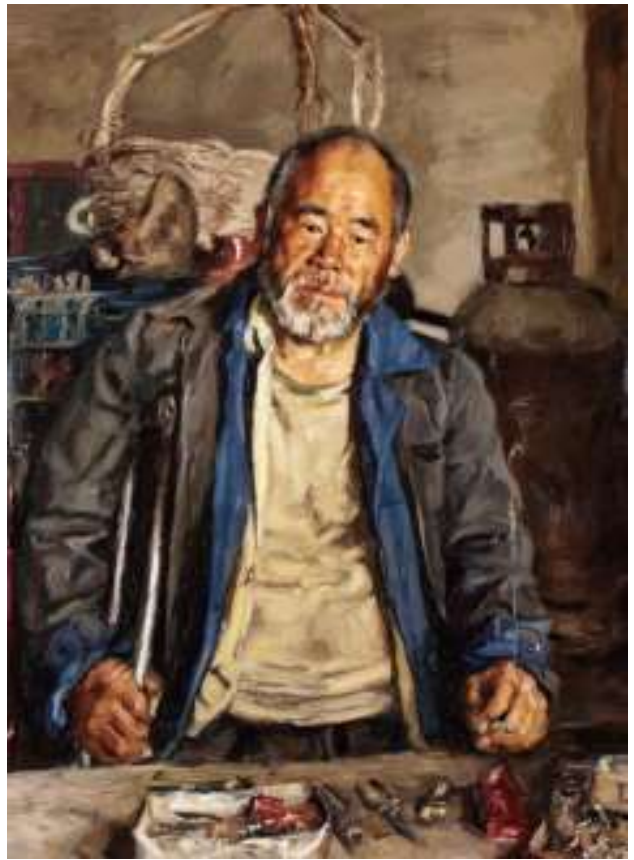

Ил.1 杨飞云《坚毅》2009年，布面油画，130x97cm， 中国艺术研究院油画院美术馆

Ян Фэйюнь 《Настойчивость» 20092, холст, масло, 130х97см, Музей Академии масляной живописи Китайской Академии художесть

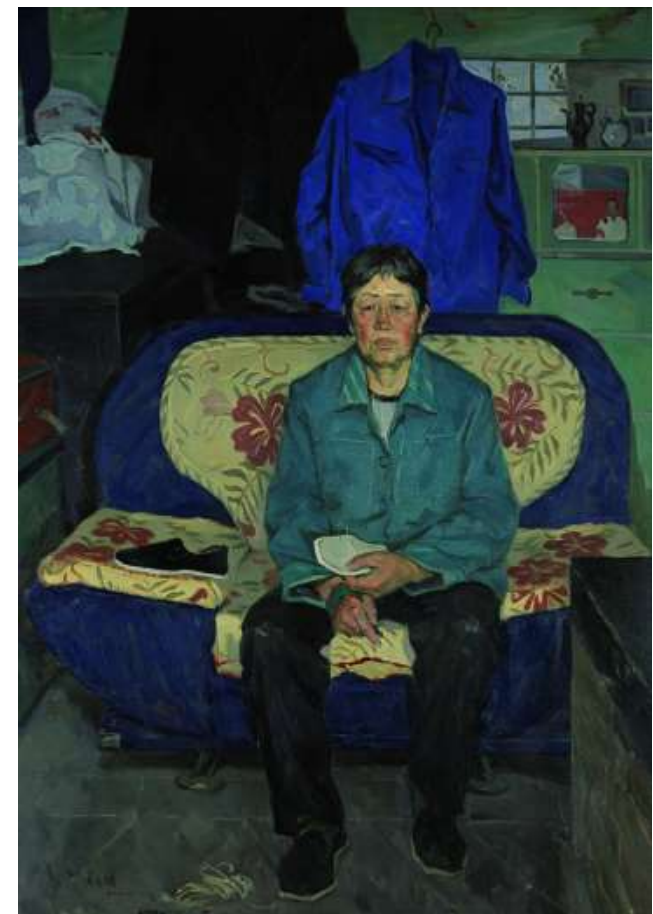

Ил.2 黄远鹏《新鞋》2012年, 布面油画, $160 \times 120 \mathrm{~cm}$ 中国艺术研究院油画院美术馆

Хуан Юаньпэн 《Новые туфли》, 20122, холст, масло, 160х120см Музей Академии масляной живописи Китайской Академии художеств 


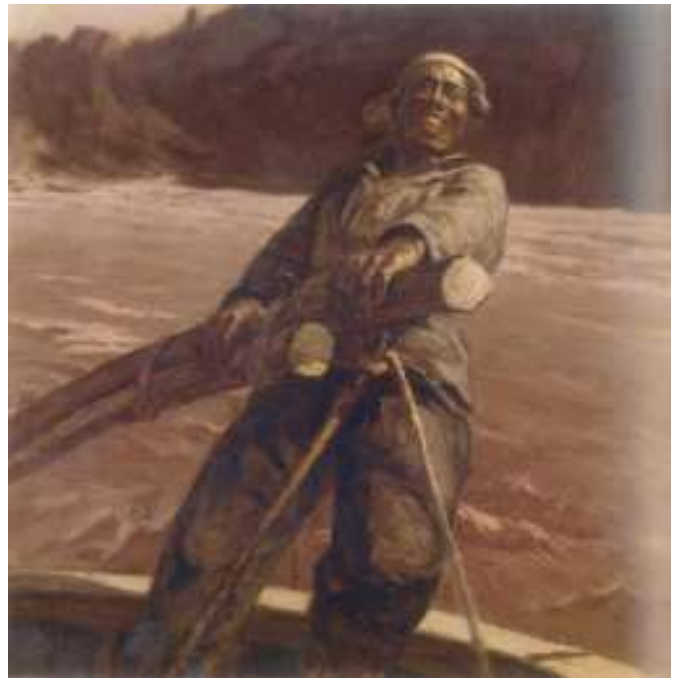

Ил.3 钟涵《山雨欲来》1982年，布面油画， $115 \times 106 \mathrm{~cm}$ 中国美术馆藏

Чжун Хань "Горный дождь идет", 1982г, холст, масло, 115х106см.

Собрание Наиионального художественного музея Китая.

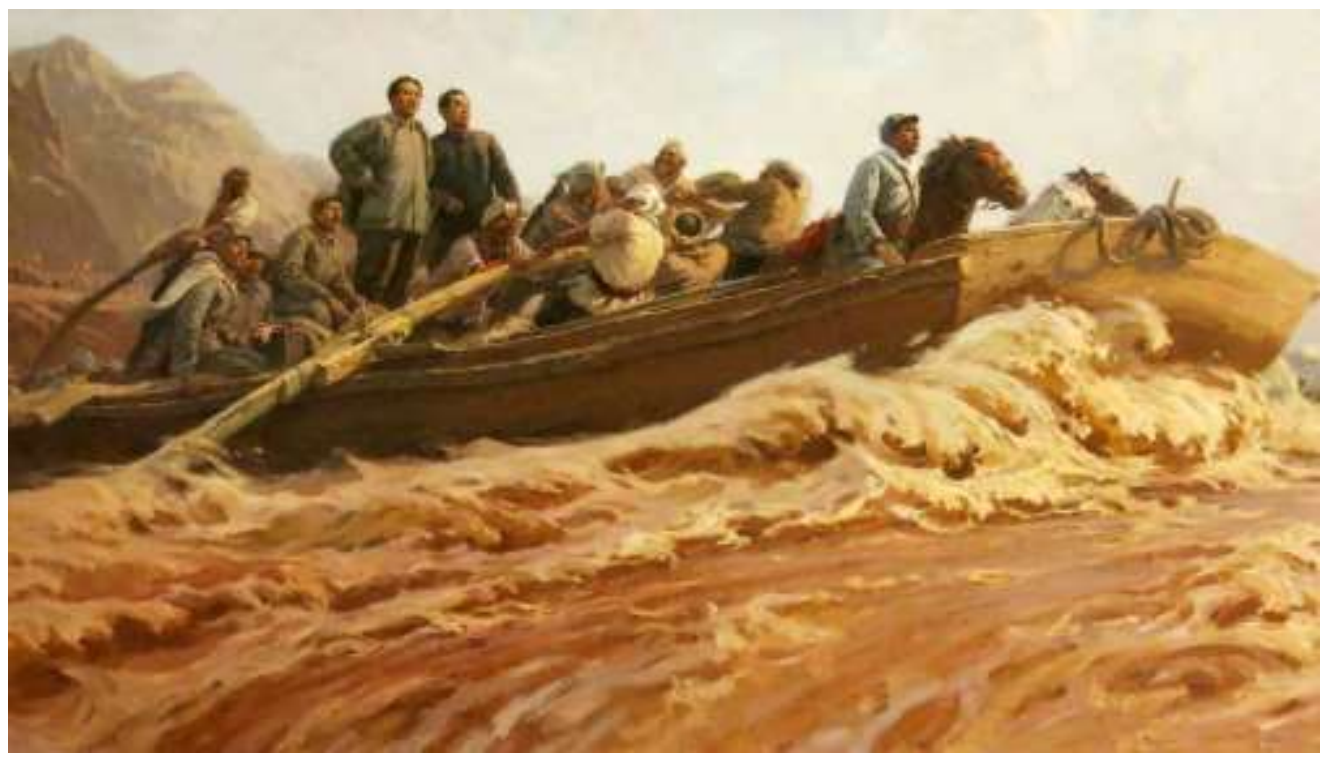

Ил.4 钟涵《东渡黄河》 (局部) $165 \times 380 \mathrm{~cm}$, 布面油画, 1976-1978年 中国 国家博物馆

Чжун Хань "Восточный переход через Хуанхэ" (фрагмент) 165х380см, холст, масло, 1976-1978 г. Национальный музей Китая 


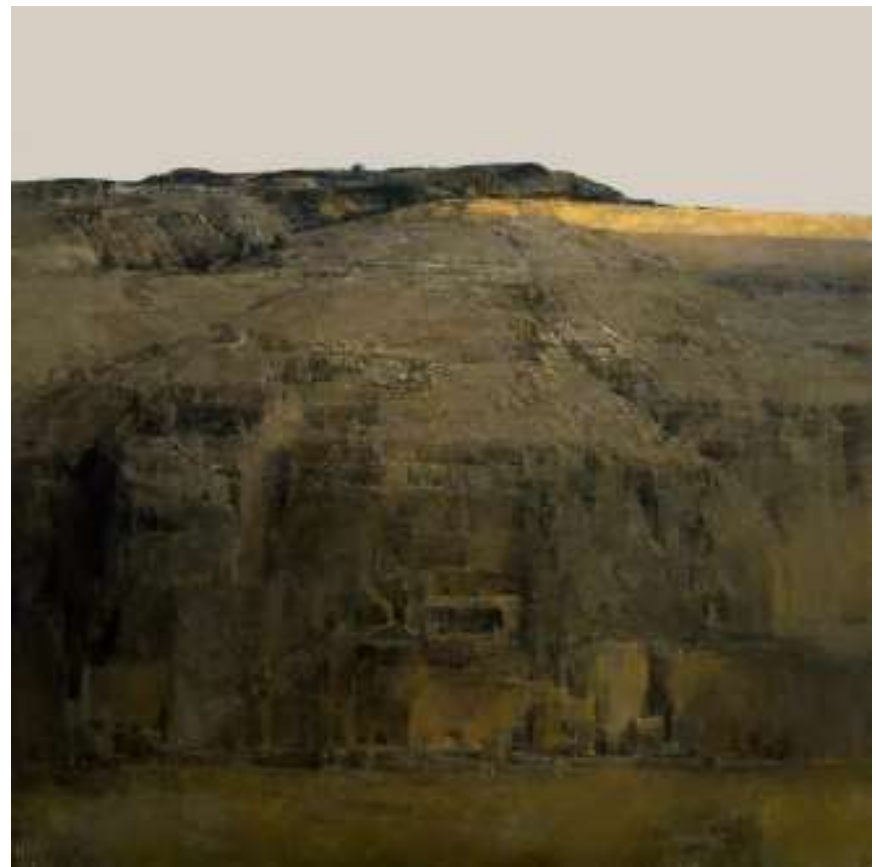

Ил.5 黄胜贤《塬上人家-暖阳》2010 年, 布面油画, $180 x 180 \mathrm{~cm} 。$ 图片源自中国油画院第一届新人展

Хуан Шэнсянь "Люди на равнинах - теплое солнце" 2010, холст, масло, 180х180см. Картина взята с первой новой выставки Китайской академии масляной живописи.

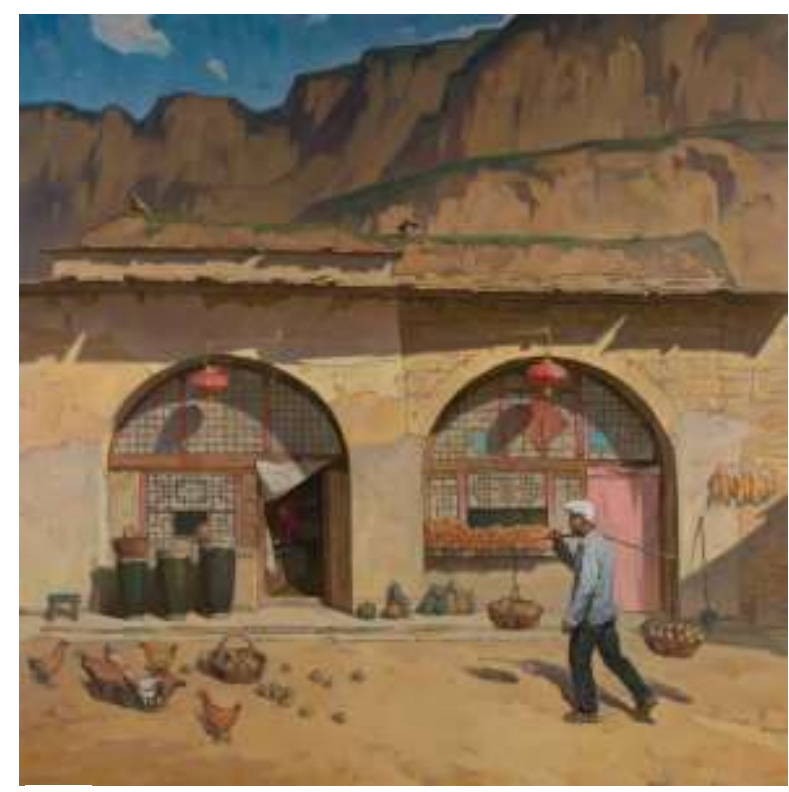

Ил.6黄远鹏《家》2019年，布面油画，180x180cm 中国艺术研究院油画院美术馆-2019年迎春展

Хуан Юаньпэн "Дом" 2019г., холст, масло, 180х180см

Китайская академия художеств Художественный музей Академии живописи-2019 Весенний фестиваль Выставка 


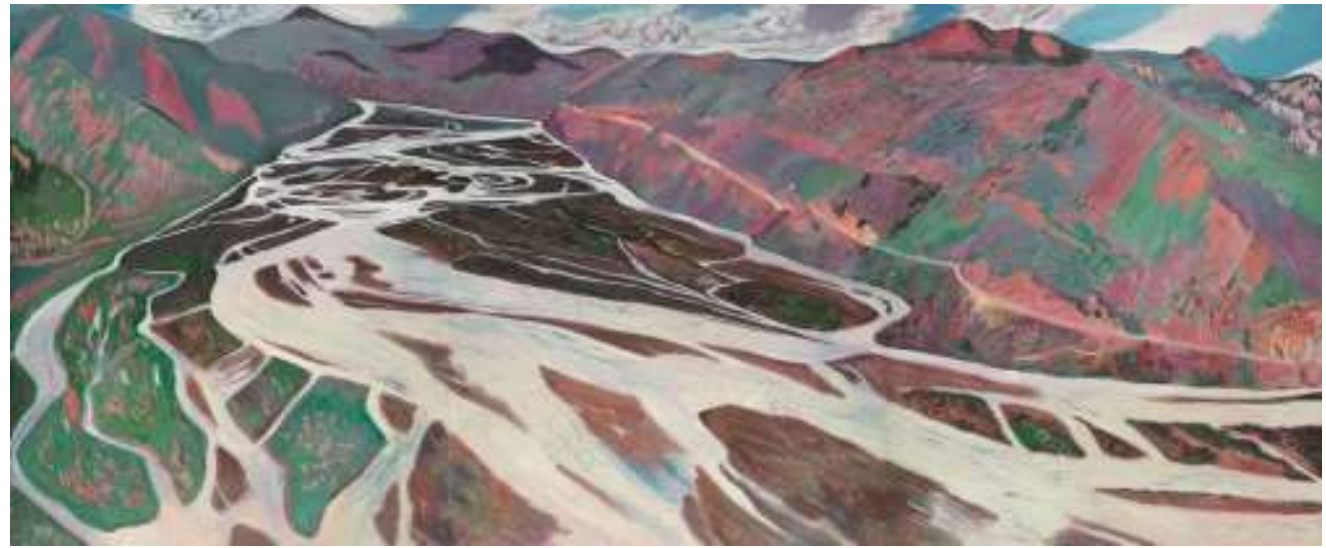

Ил.7王克举 《黄河》长卷之 (河曲) 2009-2019年作, 布面油画, $200 \times 1600 \mathrm{~cm}$ 中国美术馆藏

Ван Кеизюй. «Река Хуанхэ», (Неqu) длинный свиток, 200-2019 году, холст, масло, 200×1600 cм, коллекция Музея изобразительных искусств Китая

\title{
Информация об авторах
}

Хуан Юаньпэн - аспирант, Школа искусств и гуманитарных наук, Дальневосточный федеральный университет, г. Владивосток, Российская Федерация

\section{Художник}

Китайская академия искусств -Академия масляной живописи

(Китай, Пекин, Chaoyang District, Gaobeidian,Wenhua New Street, 1703 )

\author{
Authors \\ Huang Yuanpeng - Postgraduate Student, \\ School of Arts and Humanities, Far Eastern Federal Uni \\ versity, Vladivostok, the Russian Federation \\ painter \\ China, Beijing, Chaoyang District, Gaobeidian,Wenhua New Street, 1703 \\ Zhong guo yi shu yan jiu yuan - you hua yuan
}

